\title{
Mapping and modeling Dirofilaria infections in Europe
}

\author{
L Rinaldi ${ }^{1,4^{*}}$, V Musella ${ }^{2}, \mathrm{G}$ Marzatico ${ }^{1}$, M Mortarino $^{3}$, Genchi Claudio ${ }^{3}, \mathrm{G}$ Cringoli ${ }^{1,4}$ \\ From The 1st Conference on Neglected Vectors and Vector-Borne Diseases (EurNegVec): with Management \\ Committee and Working Group Meetings of the COST Action TD1303 \\ Cluj-Napoca, Romania. 8-11 April 2014
}

Climate change and increasing temperatures are a global phenomenon that can influence the dynamics of a number of hematophagous arthropods, vectors of pathogens with importance in human and veterinary medicine. In fact, climatic changes, together with an increase in the movement of dogs across Europe, have caused an increase in the geographical range of Dirofilaria immitis and D. repens infections. A Geographic Information System based on thermal regimen was constructed to identify areas potentially suitable for Dirofilaria transmission in Europe. These models are based on evidence that: i) there is a threshold of $14{ }^{\circ} \mathrm{C}$ below which Dirofilaria development will not proceed in mosquitoes; ii) there is a requirement of 130 growing degree-days for larvae to reach infectivity, and; iii) there is a maximum life expectancy of 30 days for a mosquito vector. The output of these models predicted that the summer temperatures (with peaks in July and August) are sufficient to facilitate extrinsic incubation of Dirofilaria even at high latitudes. Recently, an additional model was constructed to verify the influence of temperature in the course of three decades (1980-1989, 1990-1999 and 2000-2012) on the risk of infection by Dirofilaria in Italy. The results showed an expected increasing trend of temperatures, an increase of the Dirofilaria generation numbers into the mosquitoes and a significant extension of the infection risk from 5-6 months (1980-1989) to 6.5 months (1990-1999), up to more than 7 months (2000-20012). These findings show that geospatial tools are very useful for mapping, monitoring, forecasting and surveillance of both heartworm and subcutaneous dirofilariasis.

\footnotetext{
* Correspondence: Irinaldi@unina.it

'Unit of Parasitology and Parasitic Diseases, Department of Veterinary Medicine and Animal Productions, University of Naples Federico II, Naples, Italy

Full list of author information is available at the end of the article
}

\section{Authors' details}

${ }^{1}$ Unit of Parasitology and Parasitic Diseases, Department of Veterinary Medicine and Animal Productions, University of Naples Federico II, Naples, Italy. ${ }^{2}$ Department of Health Sciences, University Magna Graecia of Catanzaro, Italy. ${ }^{3}$ Department of Veterinary Science and Public Health, University of Milan, Italy. ${ }^{4} \mathrm{CIRPAR}$, Italy.

Published: 1 April 2014

doi:10.1186/1756-3305-7-S1-020

Cite this article as: Rinaldi et al: Mapping and modeling Dirofilaria infections in Europe. Parasites \& Vectors 2014 7(Suppl 1):O20.

Submit your next manuscript to BioMed Central and take full advantage of:

- Convenient online submission

- Thorough peer review

- No space constraints or color figure charges

- Immediate publication on acceptance

- Inclusion in PubMed, CAS, Scopus and Google Scholar

- Research which is freely available for redistribution

Submit your manuscript at www.biomedcentral.com/submit
() Biomed Central 